\title{
REKAYASA PERANGKAT LUNAK PENGHITUNG JUMLAH TEMPAT PARKIR TERSEDIA MENGGUNAKAN KAMERA DENGAN METODE BACKGROUND SUBTRACTION
}

\author{
Sudimanto \\ Sekolah Tinggi Manajemen Informatika dan Komputer LIKMI \\ Jl. Ir. H. Juanda 96 Bandung 40132 \\ sudianen@yahoo.com
}

\begin{abstract}
ABSTRAK
Tempat parkir merupakan salah satu fasilitas publik yang sekarang menjadi salah satu kebutuhan yang sangan penting bagi para pengguna kendaraan pribadi. Karena semakin banyaknya masyarakat yang menggunakan kendaraan pribadi terkadang didapati sulitnya mencari tempat parkir yang masih kosong pada suatu tempat penyedia tempat parkir. Sehingga sering dijumpai baik pengendara maupun pengolah tempat parkir kesulitan mengontrol kapasitas parkir pada suatu tempat parkir terutama pada saat keadaan ramai. Dan juga sering didapati suatu tempat parkir melebihi kapasitas yang dapat ditampung.

Aplikasi menggunakan kamera sebagai alat masukan berupa gambar digital, yang kemudian dari hasil tangkapan kamera tersebut aplikasi akan melakukan pemrosesan gambar yang dilajutkan dengan prosess pendeteksian ada dan tidak adanya kendaraan pada parkir yang ada. Metode yang digunakan pada pemrosesan gambar adalah metode background substraction. Metode ini berguna untuk mengeliminasi background pada hasil tangkapan kamera, hasil dari metode background substraction tersebutlah yang selanjutnya akan dilakukan proses deteksi kendaraan. Lalu dari hasil deteksi tersebut aplikasi akan menghitung jumlah tempat parkir yang tersedia dan menampilkannya.
\end{abstract}

Kata kunci : Tempat Parkir, Kamera, Background Subtraction

\section{PENDAHULUAN}

Kendaraan merupakan suatu hal yang tidak dapat dilepaskan dalam kehidupan sehari-hari. Kebutuhan masyarakat akan adanya kendaraan pun meningkat seiring dengan berkembangnya jaman. Hampir kemanapun tujuan yang dituju, seseorang memerlukan suatu kendaraan yang dapat digunakan untuk memudahkan dan mempercepat waktu tempuh dalam berpindah dari 1 lokasi ke lokasi lain. Pihak penjual kendaraan juga mengikuti keinginan pasar yang ingin mempunyai kendaraan pribadi. Sehingga apabila diperhatikan, jalur transportasi semakin lama semakin padat dengan kendaraan-kendaraan, baik berupa kendaraan beroda 2 ataupun beroda 4 .

Peningkatan populasi masyarakat yang menggunakan kendaraan pribadi dalam bepergian berdampak pada sering penuhnya lahan tempat parkir umum yang disediakan. Sehingga bagi pengendara kendaraan sulit untuk mencari tempat parkir yang masih kosong terutama bagi pengguna kendaraan roda 4 . Terkadang dijumpai kendaraan yang masuk ke dalam tempat parkir melebihi kapasitas tempat parkir tersebut. Untuk menangani masalah kendaraan yang masuk melebihi kapasitas tempat parkir, pihak penyedia jasa tempat parkir biasanya sering mengatasinya dengan cara melakukan pengecekan dan penghitungan 
manual kapasitas mobil yang masih dapat masuk, dan secara manual menaruh palang yang berisikan tempat parkir penuh.

Cara penanggulangan tersebut pada tempat parkir yang kecil dapat dibilang efektif, tetapi bagi lahan parkir besar cara manual tersebut dapat dibilang kurang efektif. Sehingga penulis ingin membuat suatu rekayasa perangkat yang dapat menghitung secara otomatis jumlah tempat parkir kosong dengan memanfaatkan komponen yang sudah menjadi salah satu bagian dari tempat parkir yaitu kamera, yang nantinya jumlah tempat parkir tersedia yang terditeksi dari kamera tersebut dapat ditampilkan dan pengendara dapat mengetahui jumlah tempat parkir yang kosong.

Gambar yang diambil melalui kamera merupakan sebuah gambar digital (digital image). menurut Rafael C. Gonzalez dalam bukunya yang berjudul "Digital Image Processing third edition", mengatakan bahwa :

"An image may be defined as a two-dimensional function, $f(x, y)$, where $x$ and $y$ are spatial (plane) coordinates, and the amplitude of $f$ at any pair of coordinates $(x, y)$ is called the intensity or gray level of the image at that point."

Berdasarkan kutipan diatas digital image dapat didefinisikan sebagai fungsi 2 dimensi dimana $\mathrm{x}$ dan $\mathrm{y}$ adalah spasial koordinat, dan disetiap koordinat dari $\mathrm{x}$ dan $\mathrm{y}$ tersebut disebut intensitas atau tingkat keabuan pada titik tersebut. Sedangkan menurut Darma Putra dalam bukunya yang berjudul "Pengolahan Citra Digital", mengatakan bahwa "suatu citra dapat didefinisikan sebagai fungsi $f(x, y)$ berukuran $M$ baris dan $N$ kolom, dengan $x$ dan $y$ adalah koordinat spasial, dan amplitude $f$ di titik koordinat $(x, y)$ dinamakan intensitas atau tingkat keabuan dari citra pada titik tersebut"

Berdasarkan kutipan-kutipan diatas penulis menarik kesimpulan digital image merupakan data 2 dimensi yang mempunyai nilai spasial (letak) dan nilai kebuan

\section{DESKRIPSI KONSEP REKAYASA PERANGKAT LUNAK PENGHITUNG JUMLAH PARKIR MENGGUNAKAN KAMERA DENGAN METODE BACKGROUND SUBSTRACTION}

Konsep rekayasa perangkat lunak ini adalah mengambil gambar dengan menggunakan kamera yang terpasang pada tempat parkir, kemudian menampilkan di layar monitor. Gambar yang diambil oleh kamera bersifat digital dan jika perhitungan tempat parkir pun masih dilakukan dengan manual, dengan menggunakan metode background substraction perhitungan tempat parkir yang tersedia dapat dihitung secara otomatis.

Metode background substraction adalah sebuah metode yang digunakan untuk mempermudah pengenalan objek. Menurut Ahmed Elgammal pada bukunya yang berjudul "Background Substraction Theory and Practice" mengatakan bahwa : "Background substraction algorithms in general from all other detection and segmentation is that they maintain a representation of the scene background, and use this representation to help detect the foreground objects"

Lain halnya metode background substraction yang dikutip dari open cv menyatakan bahwa : "Background subtraction (BS) calculates the foreground mask performing a subtraction between the current frame and a background model, containing the static part of the scene or, more in general, everything that can be considered as background given the characteristics of the observed scene."

Berdasarkan kutipan tersebut dapat dikatakan bahwa background substaction secara umum digunakan untuk menghitung foreground mask dengan melakukan pengurangan antara frame dan background. 
Proses background subtraction pada rekayasa ini terdiri dari beberapa tahap yaitu: setelah gambar ditangkap oleh kamera sistem ini akan melakukan perubahan warna. Perubahan yang dilakukan adalah merubah warna menjadi warna abu-abu. Setelah merubah gambar ke warna abu-abu langkah selanjutnya adalah melakukan ekstraksi latar belakang sehingga didapat sebuah nilai threshold. Nilai threshold ini menjadi pembanding ada atau tidaknya sebuah objek di tempat parkir dalam kasus ini adalah mobil.

\section{REALISASI RANCANGAN PERANGKAT LUNAK}

Rekayasa penghitung tempat parkir dibuat ke sebuah sistem perparkiran yang dijalankan oleh operator. Gambar 1 menunjukan menu-menu dari sistem yang digambarkan dalam bentuk use case. Saat sistem dijalankan maka akan melakukan pengecekan kondisi tempat parkir dengan menggunakan kamera sebagai alat pengambil gambar. Lalu aplikasi akan menggunakan hasil dari pengcekan tersebut dan menghitung jumlah parkir kosong yang ada, lalu menghitung jumlah tempat parkir tersedia berdasarkan jumlah parkir kosong dan jumlah kendaraan masuk. Ketika terdapat kendaraan yang ingin memarkirkan kendaraan dan menekan tombol masuk parkir maka program akan menyimpan waktu masuk kendaraan. Ketika kendaraan meninggalkan tempat parkir maka operator akan menekan tombol keluar parkir dan menyimpan waktu keluar kendaraan. Hasil tangkapan kamera dan data kendaraaan masuk dapat dilihat pada menu kondisi parkir dan data parkir.

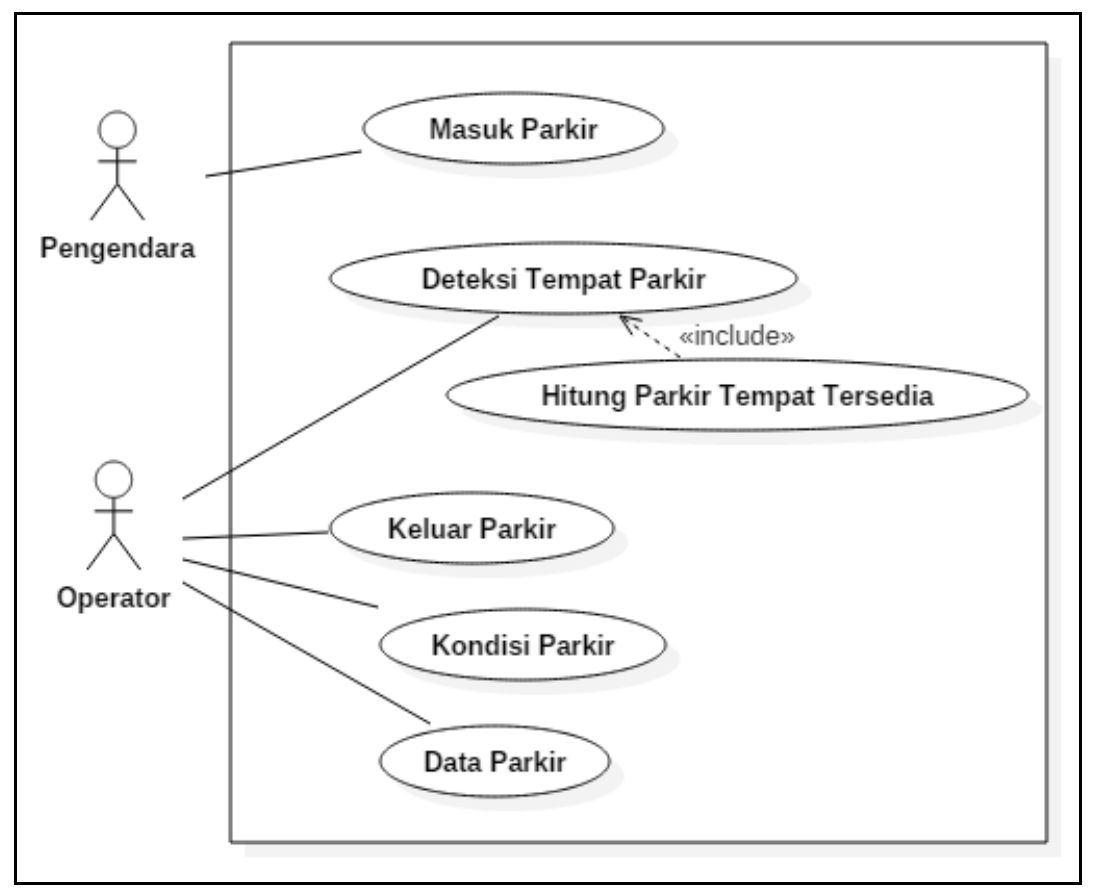

Gambar 1

Use Case Diagram

Gambar 2 merupakan class diagram pada sistem ini guna untuk mengambarkan datadata apa saja yang tersimpan. Pengambilan gambar yang dilakukan pada kamera akan diolah pada class FrmParkir untuk dideteksi jumlah tempat parkir kosong pada tempat parkir tersebut. Class TempatParkir akan melakukan perhitungan jumlah tempat parkir tersedia menggunakan method yang terdapat pada class TempatParkir berdasarkan pada jumlah tempat parkir kosong dan jumlah mobil yang masuk. Class FrmData akan menampilkan data jam masuk dan keluar kendaraan pada tempat parkir tersebut. 


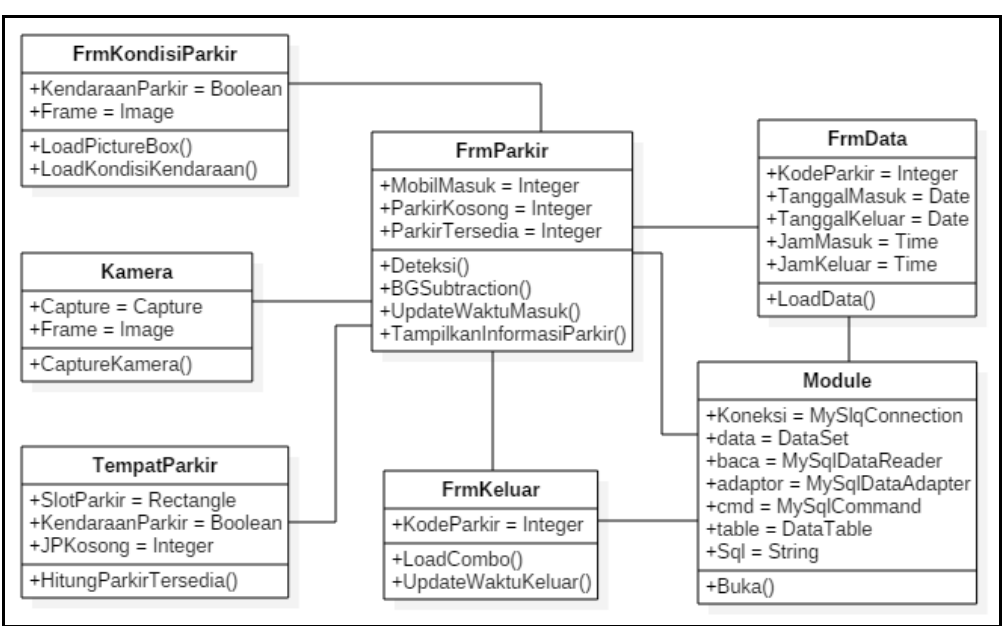

Gambar 2

Class Diagram

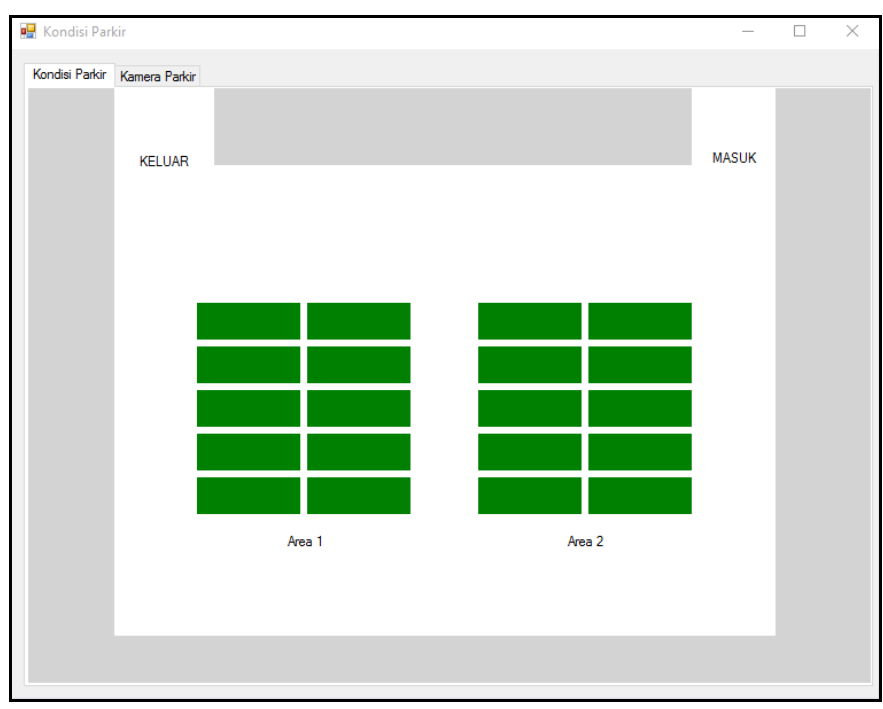

Gambar 3

Kondisi Parkir dalam Keadaan Kosong

Hasil pembacaan dari kamera diolah menggunakan metode yang kemudian ditampilkan di monitor seperti yang ditunjukkan pada gambar 3 dapat dipanggil dari menu awal sistem ini. Sedangkan jika sistem membaca kondisi parkir terisi maka gambar yang ditampilkan terlihat seperti Gambar 4. 


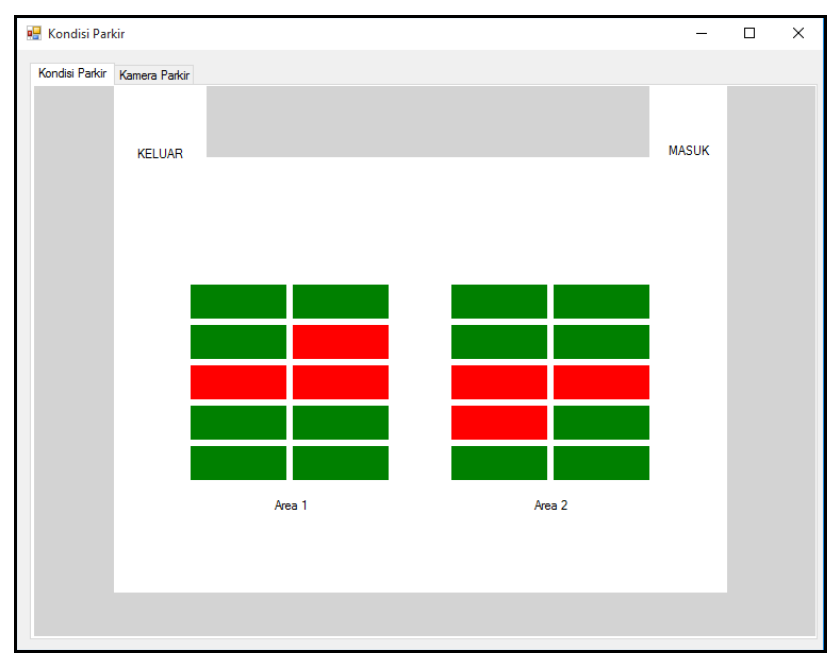

Gambar 4

Tampilan Tempat Parkir Terisi Sebagian

\section{KESIMPULAN} berikut:

Kesimpulan yang dapat ditarik dari hasil percobaan dari sistem ini adalah sebagai

a. Pembuatan aplikasi berbasis image processing tersebut dimulai dari pembuatan kode program untuk dapat membaca hasil masukkan kamera berupa gambar kondisi parkir.

b. Cara pengenalan tempat parkir kosong dan tidak dimulai dengan pengolahan gambar kondisi parkir dari kamera dan menghilangkan gambar background sehingga gambar menyisahkan objek-objek yang nantinya akan dilakukan proses thresholding lalu objek yang terdeteksi akan dipilah berdasarkan ukuran nya.

c. Berdasarkan hasil pengujian yang telah dilakukan, hasil pendeteksian menggunakan metode background substraction cukup baik. Dengan nilai keberhasilan sebesar $78.316 \%$ dari total percobaan dengan berbagai macam kondisi cahaya dan nilai thresholding yang berbeda.

\section{DAFTAR PUSTAKA}

[1] Elgammal, Ahmed, 2014, "Background Substraction Theory and Practice", Morgan \& Claypool Publishers

[2] Gonzales, Richard, Richard E.Woods, 2008, "Digital Image Processing third edition", Pearson Education,Inc.

[3] Putra, Darma, 2010, "Pengolahan Citra Digita", C.V ANDI OFFSET

[4] http://docs.opencv.org/3.2.0/d1/dc5/tutorial_background_subtraction.html 